\title{
Research on the Impact of Budgetary Participation on Management Performance Based on Meta-analysis
}

\author{
Yao GE ${ }^{a, *}$ and Xiao-Na DENG ${ }^{b}$ \\ School of Nanjing University of Science and Technology, Nanjing 210094, China \\ ageyaodd@163.com, bdengxiaona_ivy@sina.com \\ ${ }^{*}$ Corresponding author
}

Keywords: Budget participation, Management performance, Meta - analysis.

\begin{abstract}
The relationship between the participating budget and performance is hot but not yet resolved unanimously in management accounting research. In this paper, meta-analysis is used to explore whether methodological concerns (sample selection) and theoretical concerns (cultural differences) help explain observed differences in present relevant research results. Consistent with the prediction, the overall participating budgeting-performance relation is significant positive and heterogeneous, however, sample selection methods and cultural differences do not regulate the relationship between budget participation and management performance.
\end{abstract}

\section{Introduction}

With the development of economy, the issue of management and control has been paid more and more attention. It has become a hot topic in the field of theory and practice at home and abroad. The budget is the core of the process of enterprise management and control. It is guided by the strategic goal of the enterprise and not only helps management understand the financial status of the business and business results, but also can be used as a means to motivate managers to complete the goal and an important indicator of performance evaluation. Since Argyriy [1] linked individual behavior with the budget, it has made up for the unilateral nature of past budget research neglecting individual behavior. The budget participation has drawn extensive attention from both the theoretical and the practical circles.

In the study of budgetary participation, performance is the necessary result of management [2]. Although there is strong evidence of economic and psychological support for the positive relationship between budget participation and management performance [2,3], non-obvious or even negative relationships have also been reported. The differences among the theorists in the study of the relationship between budget participation and management performance provide (1) explanations based on contingency theory and (2) intermediate variables, and given the importance of understanding the relationship between budget participation and performance, it is necessary to develop a systematic analysis between the difference of studies.

In this paper, a meta-analysis is used to conduct a quantitative reanalysis of the relationship between published budget engagement and management performance and to analyze the underlying methodology (e.g. sample selection) and the theoretical (e.g. cultural) factors that affect the relationship.

\section{Literature Review and Research Hypothesis}

\section{Definition of Budget Participation}

All aspects of management accounting are closely related to the budget, such as cost accounting, accountability, performance appraisal and compensation, and budgets are often used for planning and coordinating organizational activities, resource allocation and employee motivation [3]. Argyris [1] argues that authoritarian budgets can create cognitive differences among employees, which can lead to stress, interpersonal conflicts, distrust and ultimately lead to negative functional behaviors, but budget participation can be used as a means to alleviate this problem. Since then, the budgetary participation has drawn wide attention in both the theoretical and the practical circles. Scholars have tried to define the 
concept of budgetary participation according to their own research content and purpose. Throughout the definition of budget participation by scholars at home and abroad, there are two aspects: the participation and influence of budget decision-making, so the definition of budget participation in this paper will follow the definition of budget participation by Shields and Shields [2], that is that managers participate in and affect their budget level settings.

\section{The Overall Effect of Budgetary Engagement on Management Performance}

Both agency and psychological theory show that budget participation positively influences management performance. According to the agency theory, due to the asymmetric information between the shareholders and the agents, the agents may deceive the shareholders for their own purposes. In order to alleviate this problem and to make shareholders and agents consistent with their purposes, a budget-based incentive contract was put in place [4]. This type of contract requires that the agent participate in the budget making process so that the agent's private information is integrated into the final budget decision, and finally the two benefits are obtained. First, integrating the agent's private information into the budget can generate more realistic budgetary goals, and to the effective allocation of resources. Second, budgetary decisions that result from budget-based incentive contracts can inspire higher efforts from agents. By incorporating both impacts, budgetary engagement increases management performance [5].

According to psychological theory, budgetary participation has a positive effect on performance through incentives. Through incentives, budgetary engagement increases subordinates' trust, self-control, and self-reliance on the organization, which causes less disagreement about change, greater acceptance and investment in budgetary decisions that in turn can lead to managerial performance Improve [2].

Although agency theory and psychological theory cannot directly reflect the direct relationship between budget participation and management performance, they indirectly support the positive relationship between budget participation and performance.

Hypothesis 1: Budget participation is positively correlated with management performance.

\section{Regulatory Effect of Relevant Factors on the Relationship between Budgetary Participation and Management Performance}

Sample Selection Method. The samples of Lau et al. [6] were randomly selected from multiple organizations. The relationship between budgetary engagement and management performance was positive. Cheng [7] used a non-randomized and multi-organizational sample, The relationship between budgetary engagement and management performance is negative. Although Derfuss [8] found that random and non-random sample selection does not regulate the relationship between budget participation and performance, Ostroff and Harrison [9] pointed out that the discrepancy between random and non-random is closely related to the difference between single and multiple organizations . Multi-tissue samples can produce the results of the overall level of correlation, and single-tissue samples can only produce the relationship within the organization, not as an assessment of the overall effect. Combining the effects of stochastic and non-stochastic, multiorganizational and single organizations may explain the discrepancy between the study of budget participation and management performance.

Hypothesis 2: The effects of stochastic, non-stochastic and non-stochastic tissue samples on the relationship between budget participation and management performance are significantly different.

Cultural Difference. Hofstede[10] believes that national or regional differences can be one of the most critical issues in management. One of the main manifestations of differences between countries or regions is cultural differences, especially transnational and cross-cultural organizations. Research on budget participation and management performance covers a large number of countries. According to the division of prevailing cultural differences, it includes both Eastern culture and Western culture. An important indicator of East-West culture is individualism and collectivism. Rao Yulei et al [11] think that regional cultural differences (individualism, collectivism) can affect people's decision-making preferences. The degree of budget participation and the estimation of performance evaluation included in the study are both an expression of managers' preferences. managers with stronger individualism may report more realistic or even lower level of budget participation and managerial performance, while 
collectivist managers may choose to report higher levels of budget participation and performance in the interests of the company.

Hypothesis 3: Compared with western culture, the relationship between budgetary engagement and management performance is stronger under the oriental cultural background.

\section{Research Design}

Meta-analysis is a kind of statistical analysis, which is to combine statistical results of multiple independent research results with the same purpose, to quantitatively analyze and analyze the characteristics of the differences between the studies, and to comprehensively evaluate the results of the existing research [12]. This article mainly for the retrieval of documents from the following aspects. First, foreign literature is searched through "budgetary participation", "participative budgeting" and "performance" keywords in the database of EBSCO, ELSEVIER, JSTOR, Springer, John Wiley, Emerald and so on. Second, the Chinese literature mainly uses keywords "Budgeting Participation" searches from CNKI Database, Wanfang Database and Baidu Academic. Finally, 48 independent samples were obtained from 60 articles.

\section{Data Analysis Results}

\section{Publication Bias Analysis}

Publication bias, also known as prejudice, refers to the fact that the literature that reported significantly positive or negative correlations is more likely to be published than the ones that reported weak or insignificant contributions, since meta-analysis uses published research as a target of analysis, then the assessment of the results may be affected by published prejudices. In order to address this issue, the use of funnel charts prior to the hypothesis test to verify the publication bias of the included literature. As a result, the issue of publication bias was found not to be so serious that subsequent data analysis was conducted.

\section{Hypothetical Test}

Panel A in table 1 reports a meta-analysis of overall budget participation and management performance. The relationship between budget participation and management performance is significantly and positively correlated $(\mathrm{r}=0.313, \mathrm{P}<0.001)$ and the groups are heterogeneous $(\mathrm{I} 2=$ $77.339 \%$ ), assumption one is supported.

Hypothesis 2 shows that there is a significant difference in the impact of random multi-organization, non-random single-organization and non-random multi-tissue samples on the relationship between budgetary engagement and management performance. The relevant test results are shown in panel B of table 1 . Hypothesis 2 can not be supported because subgroup differences were not significant $(\mathrm{P}=0.119)$.

Hypothesis 3 shows that the relationship under the oriental cultural background between budgetary participation and management performance is stronger than that of western culture. Hypothesis 3 is not supported because there is no significant difference between oriental culture and western culture subgroups $(\mathrm{P}=0.296)$.

\section{Conclusion}

Through the use of meta-analysis, this article further elaborates the relationship between budgetary participation and management performance, and provides a new perspective for this hotly discussed but inconclusive area of research. Consistently with research [8], the overall relationship between budget participation and management performance is significantly positive, but the regulatory role of the two chosen regulatory variables (sample choice and cultural differences) has not been validated and therefore requires to explore the impact of budgetary engagement and management performance through other variables (e.g. performance measures, variable measurement methods, industry differences, etc.). 


\section{References}

[1] Argyris C. The impact of budgets on people: a study prepared for the Controllership Foundation, $\operatorname{Inc}[\mathrm{M}] .1952$.

[2] Shields J F, Shields M D. Antecedents of participative budgeting[J]. Accounting, Organizations and Society, 1998, 23(1): 49-76.

[3] Covaleski, M. A., Evans III, J. H., Luft, J. L., Shields, M. D.. Budgeting research: three theoretical perspectives and criteria for selective integration[J]. Journal of Management Accounting Research, 2003,15(1), 3-49.

[4] Sprinkle G B, Williamson M G, Upton D R. The effort and risk-taking effects of budget-based contracts[J]. Accounting, Organizations and Society, 2008, 33(4): 436-452.

[5] Heinle M S, Ross N, Saouma R E. A theory of participative budgeting[J]. The Accounting Review, 2013, 89(3): 1025-1050.

[6] Lau C M, Tan S L C. Budget Targets as performance measures: the mediating role of participation and procedural fairness[J]. Advances in Management Accounting, 2012, 20: 151-185.

[7] Cheng M T. The joint effect of budgetary participation and broad-scope management accounting systems on management performance[J]. Asian Review of Accounting, 2012, 20(3): 184-197.

[8] Derfuss K. The relationship of budgetary participation and reliance on accounting performance measures with individual-level consequent variables: a meta-analysis[J]. European Accounting Review, 2009, 18(2): 203-239.

[9] Ostroff C, Harrison D A. Meta-analysis, level of analysis, and best estimates of population correlations: Cautions for interpreting meta-analytic results in organizational behavior[J]. Journal of Applied Psychology, 1999, 84(2): 260.

[10] Hofstede G. The cultural relativity of organizational practices and theories[J]. Journal of international business studies, 1983: 75-89.

[11] Yulei R, Yuan Z, Chen L. Research on the Influence of Regional Cultural Differences on Individual Decision Making Preferences[J]. Statistics and Decision, 2012(22):93-98.

[12] Glass G V. Primary, secondary, and meta-analysis of research[J]. Educational researcher, 1976, 5(10): 3-8. 
Table 1 Correlation analysis of budget participation and management performance

\begin{tabular}{|c|c|c|c|c|c|c|c|c|c|c|c|c|c|c|c|}
\hline & \multicolumn{3}{|c|}{$\begin{array}{l}\text { Heterogeneity } \\
\text { among groups }\end{array}$} & \multirow{2}{*}{ Category } & \multirow{2}{*}{$\mathrm{K}$} & \multirow{2}{*}{$\mathrm{N}$} & \multicolumn{3}{|c|}{$\begin{array}{l}\text { Effect value and } \\
95 \% \mathrm{CI}\end{array}$} & \multicolumn{2}{|c|}{$\begin{array}{c}\text { Zero } \\
\text { Hypothesi } \\
\text { s Test } \\
\end{array}$} & \multicolumn{4}{|c|}{$\begin{array}{l}\text { Heterogeneity } \\
\text { within the group }\end{array}$} \\
\hline & $\mathrm{Q}$ & Df & $\mathrm{P}$ & & & & $\mathrm{R}$ & Lower & Upper & $\mathrm{Z}$ & $\mathrm{P} 1$ & Q & Df & $\mathrm{P}_{2}$ & $\mathrm{I}^{2}(\%)$ \\
\hline \multicolumn{16}{|l|}{ Panel A } \\
\hline $\begin{array}{c}\text { Manage } \\
\text { performance }\end{array}$ & - & - & - & - & 48 & 6721 & 0.325 & 0.278 & 0.372 & 12.574 & $\begin{array}{c}0.00 \\
0\end{array}$ & $\begin{array}{c}207.40 \\
9\end{array}$ & 47 & $\begin{array}{c}0.00 \\
0\end{array}$ & 77.339 \\
\hline \multicolumn{16}{|l|}{ Panel B } \\
\hline \multirow{3}{*}{$\begin{array}{l}\text { Sample } \\
\text { selection }\end{array}$} & \multirow{3}{*}{$\begin{array}{c}4.25 \\
6\end{array}$} & \multirow{3}{*}{2} & \multirow{3}{*}{$\begin{array}{c}0.11 \\
9\end{array}$} & $\begin{array}{l}\text { Non-random } \\
\text { multi-organiz } \\
\text { ation }\end{array}$ & 19 & 2474 & 0.348 & 0.269 & 0.423 & 8.146 & $\begin{array}{c}0.00 \\
0\end{array}$ & 78.658 & 18 & $\begin{array}{c}0.00 \\
0\end{array}$ & 77.116 \\
\hline & & & & $\begin{array}{l}\text { Non-random } \\
\text { single } \\
\text { organization }\end{array}$ & 6 & 888 & 0.410 & 0.303 & 0.507 & 6.965 & $\begin{array}{c}0.00 \\
0\end{array}$ & 14.952 & 5 & $\begin{array}{c}0.01 \\
1\end{array}$ & 66.559 \\
\hline & & & & $\begin{array}{l}\text { Random } \\
\text { multi-organiz } \\
\text { ation }\end{array}$ & 23 & 3359 & 0.283 & 0.212 & 0.350 & 7.541 & $\begin{array}{c}0.00 \\
0\end{array}$ & 99.845 & 22 & $\begin{array}{c}0.00 \\
0\end{array}$ & 77.966 \\
\hline \multicolumn{16}{|l|}{ Panel C } \\
\hline \multirow{2}{*}{$\begin{array}{l}\text { Cultural } \\
\text { difference }\end{array}$} & \multirow{2}{*}{$\begin{array}{c}1.09 \\
2\end{array}$} & \multirow{2}{*}{1} & \multirow{2}{*}{$\begin{array}{c}0.29 \\
6\end{array}$} & $\begin{array}{l}\text { Eastern } \\
\text { culture }\end{array}$ & 21 & 3517 & 0.352 & 0.266 & 0.432 & 7.595 & $\begin{array}{c}0.00 \\
0\end{array}$ & $\begin{array}{c}150.15 \\
7\end{array}$ & 20 & $\begin{array}{c}0.00 \\
0\end{array}$ & 86.681 \\
\hline & & & & $\begin{array}{l}\text { Wastern } \\
\text { culture }\end{array}$ & 23 & 2769 & 0.300 & 0.250 & 0.348 & 11.263 & $\begin{array}{c}0.00 \\
0\end{array}$ & 41.395 & 22 & $\begin{array}{c}0.00 \\
7\end{array}$ & 46.853 \\
\hline
\end{tabular}

Note: Df: Degree of freedom; K: number of correlation coefficients per relation; N: toatl sample size across k samples.

In the table, $\mathrm{P}$ and $\mathrm{P}_{2}$ values are for the unilateral test results and $\mathrm{P}_{1}$ value is for the two-sided test results. 